\title{
Farmers act to avert foot-and-mouth crisis
}

\section{Jim Giles, London}

Beleaguered British farmers are reeling from another animal health crisis this week, after cases of foot-and-mouth disease were confirmed at locations across the country. It is the first major outbreak of the highly infectious disease to affect Britain in over 30 years.

The government acted quickly to halt movement of animals after vets from the government-funded Institute for Animal Health (IAH) found cases at an abattoir in Essex.

Eleven further outbreaks had been confirmed by 27 February, including one at a sheep-exporting business in southwest England. The possibility that the disease may have been exported led France, Germany, Belgium and the Netherlands to introduce measures restricting movement of animals that had recently arrived from Britain.

Intensive farming practices and the increased movement of livestock, which has resulted from the closure of local abattoirs in response to the outbreak of bovine spongiform encephalopathy, have been blamed in the press for the scale of the outbreak. But experts say that these factors are of little importance.

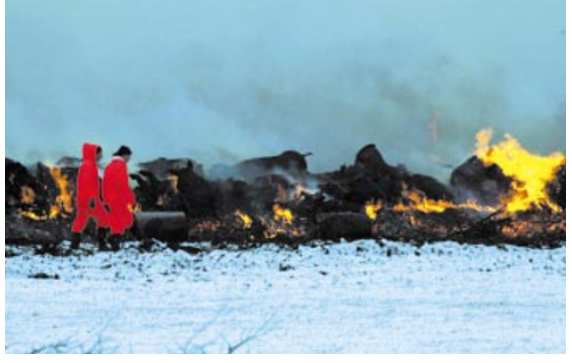

Dead meat: pyres burn in Britain as farmers struggle to contain foot-and-mouth disease.

Peter Roeder, an animal health officer at the United Nations' Food and Agriculture Organization, points out that foot-andmouth disease is already endemic in some areas of southern Africa and parts of Asia. Imports of foodstuffs from these regions are strictly controlled, but customs officials say it is impossible to block illegal imports completely.

The UK virus is one of seven known types of the disease. Called type O, it originated in India before spreading east into China, Japan, Korea and Taiwan. It arrived in South Africa last year, but has been eradicated there by slaughtering potentially infected cattle.
Slaughtering of livestock has already begun in Britain, as existing vaccines can stop symptoms but do not prevent animals from carrying or spreading the disease. "The virus can exist in vaccinated cattle for up to three years," says the IAH's Paul Kitching, "and trade restrictions reflect this. To resume trade a country has to be totally free of the disease."

Making the vaccine, which requires large amounts of the live virus, is also risky. Outbreaks from vaccine production centres have persuaded several European countries to end vaccination programmes.

Vaccine development is further complicated by the virus's high mutation rate. This leads to the existence of numerous subtypes within each type, some of which may require different vaccines. The IAH is responsible for matching vaccines to the hundreds of samples it receives from around the world every year. It dealt with 400 samples last year but, says Kitching, the true number of outbreaks is "uncountable".

The IAH, Pfizer and Eli Lilly each have groups working on new vaccines. "Safer, more stable vaccines are possible," says Kitching, "but it is highly unlikely that a new vaccine will eliminate all the problems.”

\section{Europe frames fresh funding initiative for research}

\section{Quirin Schiermeier, Munich}

Sweeping reforms to the Framework programme, the European Union's main research support activity, have been proposed by the European Commission.

Instead of supporting large numbers of unrelated projects, Framework's next phase will fund a much smaller number of large, integrated projects. The commission hopes that the change will distinguish Framework from the plethora of national research funding agencies in Europe, and make a real difference to European competence in key scientific areas.

The new programme means a particularly drastic change in the life sciences, where four-fifths of existing projects will lose support, as the focus is shifted to functional genomics.

The commission is proposing a budget of 17.5 billion euros (US\$16 billion) over five years for the next - sixth - Framework programme, which starts in 2003. This is a $17 \%$ increase on the current fifth Framework programme's budget.

But the average size of Framework grants — currently around 1.5 million euros per project - will rise by an order of magnitude. Proposed 'networks of

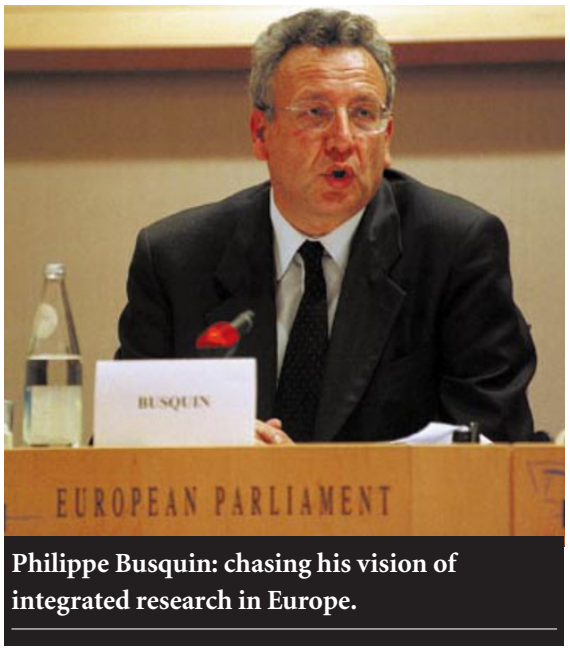

excellence' in critical scientific disciplines will, for example, receive tens of millions of euros each year.

To attract Europe's best scientists, the commission has also suggested ways of simplifying grant application procedures and project management.

The reforms are aimed at improving interaction between national and European programmes, officials say. According to one official, the commission plans to operate in "catalytic mode, building on, rather than duplicating, what happens in the member states".

The new networks of excellence are designed to complement the concept of a single 'European research area' proposed by Philippe Busquin, the European Commissioner for Research. This aims to make the best use of Europe's research resources (see Nature 405, 873; 2000).

The plan will also back large-scale integrated projects designed around specific technologies or research applications - for example, high-performance materials or information technology. Ideally, these will be conducted as partnerships between academia and industry.

Grant recipients will be allowed to take on partners as their project proceeds, instead of having them all in place at the start. And in some areas grant applications will be split into two phases, with a preliminary application being used to identify a project's most promising ideas.

The proposal is being sent to the European Union's member states for consideration. A decision on its adoption will be made next year through the Council of Ministers and the European Parliament. 